\title{
Understandings of Graduate Students on Nature of Science
}

\author{
Mustafa Serdar Koksal \\ Department of Science Education, Inonu University, Campus, Malatya,Turkey \\ Email: bioeducator@gmail.com \\ Canan Tunc Sahin \\ Department of Elementary Education, Bulent Ecevit University, Kdz Eregli, Zonguldak, Turkey \\ Email: cnntnc@gmail.com
}

\begin{abstract}
Knowing about nature of science (NOS) and its products is a basic requirement of all graduate students and researchers due to being both members of society and experts on different scientific disciplines. As the first step, determining NOS understandings of graduate students has importance to go further in developing current situation. Therefore, this study aimed to determine NOS understandings of graduate students from different disciplines. The study included seven graduate students who were enrolled in universities as researchers. As the data collection way, face-to-face interview was utilized. The data of the study was analyzed by assigning the participants to four categories; expert, naive, mixed and not applicable. The results showed that majority of the participants were expert on social and cultural embeddedness of science and role of creativity and imagination in science while majority of the participants were naive on the aspects of "hierarchy between theories and laws". Majority of them had mixed understandings on the aspects of existence of only one method in science, subjectivity, tentativeness. Interestingly, all of the participants were naive in terms of definition of science. The results and implications of the study will be discussed.
\end{abstract}

Index Terms - Nature of Science, Graduate Students, Researchers, Science.

\section{INTRODUCTION}

Science and science-related products have been incorporated into daily life day by day. This changes requirements of an individual to maintain her/his daily life in more comfortable and satisfying way. Scientific literacy as term has been defining the requirements and qualifications of contemporary science-dependent life. Scientific literacy was determined as an important aim of science education in many curriculums and international examination frameworks [1-5].

Scientifically literate individuals are effective and productive members of a society. According to Hurd, these individuals distinguish experts from the uninformed; distinguish theory from dogma, and data from myth and folklore. They also recognize that almost every fact of one's life has been influenced in one way or another by science/technology and recognize that our global economy is largely influenced by advancements in science and technology. Differently from scientifically illiterate individuals, they view sciencesocial and personal-civic problems as requiring a synthesis of knowledge from different fields including natural and social sciences and also recognize that science-social problems are generally resolved by collaborative rather than individual action [6]. In parallel to need for such individuals, societies have been adapting their curriculums to educate their children in line with requirements of being scientifically literate [12]. Scientific literacy has many aspects including content knowledge, nature of science (NOS) and affective characteristics about science. As the most frequently emphasized aspect, nature of science has been studied for a long time by different researchers [7].

Nature of science includes different aspects for science education from scientific method to science in society. The aspects of nature of science are described as the followings; "no universally accepted one way to do science", "tentative nature of scientific knowledge", "evidence and observation based science", "importance of creativeness and imagination to produce scientific knowledge", "no hierarchy between theory and law", "social and cultural embeddedness", "subjective science" and "science as a way of knowing" [8-9]. As a result of epistemological and educational studies, these aspects have been emphasized to be necessary to teach about nature of science [8]. The studies on these aspects were frequently conducted on pre-service teachers or middle, high school students [10-13]. Therefore, studies with graduate level students or researchers are needed to see whole picture of NOS understandings of individuals who took science courses during formal education and conducted scientific research and to make comparisons between educational levels in terms of gaining appropriate NOS understandings. In spite of small number of the studies, there are examples on the studies focusing nature of science understandings of graduate level students or researchers [14-15].

Irez studied with 15 Turkish prospective science teacher educators and he found that majority of the prospective science teacher educators had misunderstandings about various NOS aspects [14]. By 
approaching from epistemology perspective, Chang studied on the epistemological positions of graduate students and found that Taiwanese graduate students in the fields out of education had firmly logical positivist epistemological position about scientific knowledge [15]. In contrast, Jehng, Johnson and Anderson found that graduate students had more sophisticated ideas on tentativeness of scientific knowledge [16] and Paulsen and Wells added that age is also another contributor of difference in epistemological understandings [17]. They stated that the more people are getting older, the more they have sophisticated epistemological understandings. Marzooghi, Fouladchang and Shemshiri also found the change in age as an important factor to explain epistemological differences between younger and older university students[18].

As speculated by Paulsen and Wells, and Jehng et al.; understandings about nature of science aspects have been varying toward graduate level education [16-17]. Especially, variation might increase due to more focused and narrower specialization experiences. The most important difference between graduate and undergraduate programs is to get opportunities for studying freely on a more specific field of study. Samarapungavan, Westby and Bodner also stated that graduate students have more agency and control over their doctoral studies and might be independently study on empirical anomalies they have met[19].

The graduate students have an important place in nature of science studies due to their authentic science experiences and potential to be scientist in future. Having informed understandings about nature of science is the basic requirement for them to conduct epistemologically and theoretically sound and balanced projects. At the same time, they are also in need of being scientifically literate so that they should also be active member of society and make informed decision making on their daily problems. Therefore, determining their NOS understandings have importance for establishing more comprehensive programs and making needed changes in the graduate programs.

Based on the conflicting results on NOS understandings of graduate students and importance of having informed NOS understandings for graduate students, this study proposed to determine NOS understandings of graduate students from different departments.

The content of this paper is organized in four parts; research question, methodology, results, discussion, implications and suggestions.

\section{RESEARCH QUESTION}

The main question of this research is "What are understandings of graduate students who are conducting scientific research studies in different fields of study on nature of science?."

\section{METHODOLOGY}

In this study, qualitative research approach was utilized. The study included seven graduate students who were enrolled in universities as researchers. Table 1 is presenting characteristics of them. The participants were selected by taking into account variation in the disciplines in which they studied. Then, they were conveniently determined. As the data collection way, face-to-face interview was utilized by using the questions of VNOS-C (View on Nature of Science Questionnaire-Form C) developed by Lederman, AbdEl-Khalick, Bell and Schwartz [9]. The answers to the questions were recorded by a voice recorder and then were transcribed verbatim. The data of the study was analyzed by assigning the participants to three categories; expert, naive and mixed. Some of the participants did not provide appropriate data to determine profile of the participants on some aspects of NOS; these were categorized as "not applicable". For the categorization, a pre-determined frame provided by Lederman et al. was utilized [9]. The analysis was conducted by considering the approach used by Khishfe and Lederman, Khishfe and Abd-El-Khalick [11, 20]. The questions of the interview had generic nature, so the participants gave answers on more than one aspect of NOS in one question. In determining the profiles, the participants who answered naively on one aspect in all questions were assigned as naive while the participants who answered informedly on one aspect in all questions were categorized as expert. The participants who provided both expert and naive understandings on one aspect in their answers to all questions were assigned as mixed.

To increase trustworthiness of the data, two independent examiners have assigned the participants into profile categories. The percent agreement between the examiners has been found as $81 \%$. The discrepancies have been discussed and the final profiles have been assigned to the participants. 
TABLE I

MAIN CHARACTERISTICS OF THE PARTICIPANTS

\begin{tabular}{|c|c|c|c|c|c|c|c|}
\hline \multicolumn{8}{|c|}{ Participants } \\
\hline Characteristics & P1 & $\mathbf{P 2}$ & $\mathbf{P 3}$ & P4 & P5 & P6 & P7 \\
\hline Gender & $\mathrm{F}$ & $\mathrm{M}$ & $\mathrm{M}$ & M & $\mathrm{F}$ & M & M \\
\hline Age & 32 & 30 & 34 & 33 & 25 & 27 & - \\
\hline Occupation & Lecturer & Lecturer & Lecturer & Lecturer & $\begin{array}{l}\text { Research } \\
\text { Assit. }\end{array}$ & $\begin{array}{l}\text { Research } \\
\text { Assit. }\end{array}$ & $\begin{array}{l}\text { Research } \\
\text { Assit. }\end{array}$ \\
\hline $\begin{array}{l}\text { Taking any } \\
\text { course and } \\
\text { participating in } \\
\text { any activity } \\
\text { about } \\
\text { epistemology, } \\
\text { history of } \\
\text { science or } \\
\text { nature } \\
\text { science }\end{array}$ & Yes & No & Yes & Yes & No & Yes & - \\
\hline $\begin{array}{l}\text { Experience in } \\
\text { Occupation } \\
\text { (year) }\end{array}$ & 3 & 5 & 7 & 3 & 1 & 5 & - \\
\hline $\begin{array}{l}\text { Undergraduate } \\
\text { Education }\end{array}$ & $\begin{array}{c}\text { History of } \\
\text { Art }\end{array}$ & $\begin{array}{l}\text { Electric and } \\
\text { Electronic } \\
\text { Engin. }\end{array}$ & Civil Engin. & Mathematics & $\overline{B i o l o g y}$ & $\begin{array}{c}\text { Primary } \\
\text { education }\end{array}$ & $\begin{array}{c}\text { Business } \\
\text { Administ. }\end{array}$ \\
\hline $\begin{array}{l}\text { Graduate } \\
\text { Education }\end{array}$ & $\begin{array}{l}\text { Social } \\
\text { Studies } \\
\text { Edu. }\end{array}$ & $\begin{array}{l}\text { Electric and } \\
\text { Electronic } \\
\text { Engin. }\end{array}$ & Philosophy & $\begin{array}{l}\text { Mathematics } \\
\text { Education }\end{array}$ & Physiology & $\begin{array}{c}\text { Education } \\
\text { Programs and } \\
\text { Instruction }\end{array}$ & $\begin{array}{l}\text { Business } \\
\text { Administ. }\end{array}$ \\
\hline
\end{tabular}

\section{RESULTS AND DISCUSSION}

Under this title, the results will be presented and discussions will be made by considering relevant literature. Results of the categorization of the participants on the NOS aspects are presented in Table 2.

TABLE II

THE PROFILES OF THE PARTICIPANTS ON NINE ASPECTS OF NOS

\begin{tabular}{|c|c|c|c|c|c|c|c|c|c|}
\hline & $\begin{array}{c}\text { Only one } \\
\text { method } \\
\text { in } \\
\text { science }\end{array}$ & $\begin{array}{c}\text { Hierarchy } \\
\text { between } \\
\text { theories } \\
\text { and laws }\end{array}$ & $\begin{array}{c}\text { Observation } \\
\text { and inference }\end{array}$ & Subjectivity & $\begin{array}{c}\text { Creativity } \\
\text { and } \\
\text { imagination }\end{array}$ & $\begin{array}{c}\text { Tentative } \\
\text { ness }\end{array}$ & $\begin{array}{c}\text { Empirical } \\
\text { basis of } \\
\text { science }\end{array}$ & $\begin{array}{c}\text { Social and } \\
\text { cultural } \\
\text { embeddedness }\end{array}$ & $\begin{array}{c}\text { Definition } \\
\text { of science }\end{array}$ \\
\hline $\begin{array}{c}\mathrm{Pt} \\
1\end{array}$ & $\mathrm{M}$ & $\mathrm{N}$ & $\mathrm{M}$ & $\mathrm{M}$ & $\mathrm{E}$ & $\mathrm{M}$ & $\mathrm{NA}$ & $\mathrm{N}$ & $\mathrm{N}$ \\
\hline $\begin{array}{c}\mathrm{Pt} \\
2\end{array}$ & $\mathrm{E}$ & $\mathrm{N}$ & $\mathrm{M}$ & $\mathrm{E}$ & $\mathrm{M}$ & $\mathrm{M}$ & $\mathrm{M}$ & $\mathrm{E}$ & $\mathrm{N}$ \\
\hline $\begin{array}{c}\mathrm{Pt} \\
3\end{array}$ & $\mathrm{M}$ & $\mathrm{M}$ & $\mathrm{E}$ & $\mathrm{M}$ & $\mathrm{E}$ & $\mathrm{E}$ & $\mathrm{N}$ & $\mathrm{E}$ & $\mathrm{N}$ \\
\hline $\begin{array}{c}\mathrm{Pt} \\
4\end{array}$ & $\mathrm{M}$ & $\mathrm{N}$ & $\mathrm{E}$ & $\mathrm{M}$ & $\mathrm{M}$ & $\mathrm{N}$ & $\mathrm{E}$ & $\mathrm{E}$ & $\mathrm{N}$ \\
\hline $\begin{array}{c}\mathrm{Pt} \\
5\end{array}$ & $\mathrm{M}$ & $\mathrm{NA}$ & $\mathrm{M}$ & $\mathrm{E}$ & $\mathrm{E}$ & $\mathrm{E}$ & $\mathrm{E}$ & $\mathrm{E}$ & $\mathrm{N}$ \\
\hline $\begin{array}{c}\mathrm{Pt} \\
6\end{array}$ & $\mathrm{E}$ & $\mathrm{N}$ & $\mathrm{E}$ & $\mathrm{M}$ & $\mathrm{M}$ & $\mathrm{M}$ & $\mathrm{NA}$ & $\mathrm{M}$ & $\mathrm{N}$ \\
\hline $\begin{array}{c}\mathrm{Pt} \\
7\end{array}$ & $\mathrm{M}$ & $\mathrm{N}$ & $\mathrm{N}$ & $\mathrm{M}$ & $\mathrm{E}$ & $\mathrm{M}$ & $\mathrm{M}$ & $\mathrm{N}$ & $\mathrm{N}$ \\
\hline
\end{tabular}

Note: E: Expert, N: Naive, M: Mixed, NA: Not Applicable, Pt: Participant

As seen in Table 2, majority of the participants were expert on social and cultural embeddedness of science and role of creativity and imagination in science while all of them were naive in terms of definition of science. At the same time, majority of the participants were also naive on the aspects of "hierarchy between theories and laws". Majority of them had mixed understandings on the aspects of existence of only one method in science, subjectivity, tentativeness. The other aspects were very differently understood by the participants. The quotations from the answers of the participants on the aspects are presented below. The indicators in the 
parenthesis are illustrating participant code, NOS aspect, location and question number of VNOS-C in order.

"[There is only way used in science], yes. We can proceed through only questions. Experiments are not requirements for development of all scientific knowledge, in my field of study, experiments have different [way], [Pt4, Only one method in science, Interview, Q3].”

"Laws are proven things while theories are based on only ideas. Theories are tentative while laws are not changes [Pt6, Hierarchy between theories and laws, Interview, Q5].”

"Observations are related to things we can see in natural environments while inference is [based on] estimations we cannot see [Pt1, Observation and inference, Interview, Q6]."

"To reach different results [by using same data] is related to interest of them [scientist]. ...In production of knowledge; cultural effects of society are in case. ... The difference of science from religion and philosophy is objective nature of science [Pt3, Subjectivity, Interview, Q1, Q8]."

"I think there is a place for imagination in all aspects of life. It is a requirement for improvements. .... Absolutely, scientists have been using their creativity and imagination. I think if everything in a field is planned an in an order, it will be boring and developments are stopped [Pt5, Creativity and imagination, Interview,Q10]."

"If new knowledge is added, new perspectives are developed, [theories can change]. Laws are completely accepted. ... Laws are not changeable [Pt7, Tentativeness, Interview, Q4, Q5].”

"Science is based on more concrete evidence and depends on verification while philosophy depends on questioning, but discriminating science from philosophy is very hard. I think both of them are related to each other [Pt2, Empirical basis of science, Interview, Q1].”

"In production of [scientific] knowledge, there is an impact of culture. There is a clear example that Vygotsky and Piaget provided different theories as social constructivism and cognitive constructivism. [ by reflecting their cultural their cultural and social values] [Pt3, Social and cultural embeddedness, Interview, Q9].”

"Science is a group of knowledge that is based on theories [Pt2, Definition of Science, Interview, Q1]."

In the literature, there are studies supporting the results of this study. Schwartz and Lederman have studied on 24 scientists who are at different scientific disciplines [21]. The authors have applied questionnaire (VNOS-Sci) and interview techniques to collect data. The results of their study has shown that nearly half of the scientists have had expert understanding on tentativeness while other half of the participants have had naive and mixed understandings on the same aspect. Again, they have shown that $66.7 \%$ of the participants have also had expert understandings on role of creativity in science. Similarly to the result of this study, majority of the scientists have presented expert views on sociocultural effects on science while they have also seen naively a hierarchy between theory and law. As another study supporting this study, Samparapungavan, Westby and Bodner have studied on 13 scientists and 22 graduate students by focusing on enacted epistemologies during their projects. The authors have shown that $77 \%$ of graduate students and $54 \%$ of scientists have not provided sophisticated and contemporary definition of science [19]. Koksal has also studied on similar group and the author has found as similar to the results of this study that graduate students have misunderstandings on "hierarchy between theories and laws" and "definition of science" aspects of NOS [22].

The results of this study have shown that graduate students in different scientific disciplines have presented both similar and different understandings on NOS. In spite of similarities, there is no common understanding among the participants; this can be explained by both their difference in experience on scientific studies which are specific to their fields and personal experiences on science. Personal experiences are very effective factors in shaping understandings of individuals on science. Similarity in their understandings on definition of science might be explained by common science curriculum for all children in Turkey and stereotyped definitions of science in Turkish science textbooks [23]. As another similarity in understandings, hierarchy between theory and law might be related to previous exposure to naïve definitions of these terms in different resources. Taskin et al. have studied on theory concept with the 572 undergraduate students and they have found the participants have believed existence of a hierarchy between theory and laws. Then, the authors have asked the participants; "what can be resources for your naïve understandings", the participants have answered the question by referring to false teacher definitions and naïve definitions in textbooks [24].

\section{V.DISCUSSION, IMPLICATIONS AND SUGGESTIONS}

The results of this study have showed that varied graduate experiences in different fields are not enough to improve NOS understandings of graduate students. The participants have expert understandings on only two aspects; creativity and imagination in science and effect of socio-cultural factors on science. Majority of the answers have been coded as mixed. This is an indication of lack of improved understandings on the NOS aspects to use in informed decision making. The group of the study needs to be expert in understanding on NOS 
aspects due to their continuous involvement in scientific process and being informed decision maker on daily life situations. Results of this study refer to need for elimination of naive understandings on NOS at graduate level. The explicit-reflective implications embedded in graduate courses might be helpful to increase expert understandings of the participants [10-11]. As another suggestion, enacted epistemologies of the participants might be shown by providing continuous feed-back on the aspects during a project conducted by graduate students [19].

When look at the individuals, it has also been seen that experience in research and taking any course on and participating in any activity related to epistemology, history and nature of science are not effective factors to improve NOS understandings. Moreover, the participant who is graduate student in philosophy department has also presented naive views similar to other graduate students.

As an interesting point, none of the participants as active members of scientific research community have defined science in a manner that contemporary definition accepts it. As a suggestion, the effectiveness of courses or activities on NOS teaching should be improved by using individual means such as inserting a NOS reflection part into personal lab report format. At the same time, the graduate courses should include contemporary critics on science and its aspects.

Variation in understandings has been showing that the participants have presented both similarities and tendencies to understand some aspects and discrepancies on a different group of the aspects. The most varied profiles have been provided for observation and inference difference and empirical basis of science. This result might be related to difference in observation ways of different scientific disciplines. For example, zoologists use direct observation while a molecular biologist uses indirect ways of observation; reaction time differences. Similarly, frequency of need to make inferences might be different in two different disciplines. Frequently a zoologist can directly classify animals while molecular biologists need to make inferences to classify an animal by using molecular evidence. For the other aspects, the participants have presented less varied understandings. This might be an evidence for independence of NOS understandings from scientific discipline. Only one of the participants (Pt5) has expert understandings on over half of the aspects. It might be related to individual experiences and context in which she has encountered.

Based on the results of this study, it can be suggested that the study should be extended by using more comprehensive analysis techniques such as phenomenography to establish individual cognitive maps of the individuals based on their personal experiences. As another suggestion, the future studies should measure epistemological beliefs of the participants and think of NOS and epistemological beliefs together to see roots of the relationship between individual experiences and NOS understandings. The study has a limited number of the participants; therefore, there is a need to reach more participants in each discipline of science. By this way, discrepancies in individual contexts for the same discipline can be explained.

This study has some limitations, so the interpretation of the results should be made carefully. The participant number of the study is limited to seven. At the same time, the data resources are limited to interview answers on the aspects of NOS. As another limitation, the aspects which are studied are also limited to nine aspects of NOS. The future studies should take these points into account.

\section{REFERENCES}

[1] Turkish Ministry of Education. Ninth Grade Biology Curriculum. Ankara, Turkey. 2007.

[2] AAAS. Benchmarks for Science Literacy, Project 206, Science Literacy for a Changing Future. Report of American Association for the Advancement of Science. Retrieved on November 2012 from (http://www.project2061.org/). 1994.

[3] Kjaernsli, M. and Lie, S. PISA and scientific literacy: Similarities and differences between the Nordic countries. Scandinavian Journal of Educational Research, 48(3), 271-286.2004.

[4] Olsen, R.V., Kjærnsli, M. and Lie, S. Using single items in PISA to explore international diversity in scientific literacy. Paper presented at the 5th ESERA conference Barcelona, Spain. 2005.

[5] OECD. The PISA 2003 assessment framework: Mathematics, reading, science and problem solving knowledge and skills. Paris: OECD. 2003.

[6] Hurd, P.D. Scientific Literacy: New Minds for a Changing World. Science Education, 82 (3), $407-$ 416. 1998

[7] Lederman, N. G. Nature of science: Past, present, and future. In Abell, S. \& Lederman, N. (Eds.) Handbook of Research on Science Education. Mahwah, New Jersey: Lawrence Erlbaum Associates, Publishers. 2007.

[8] McComas, W. F. The Principle Elements of the Nature of Science: Dispelling the Myths. In W.F. McComas (Ed.), The nature of science in science education: Rationales and strategies (pp. 53-70). Dordrecht, the Netherlands: Kluwer Academic Publishers. 1998.

[9] Lederman, N.G., Abd-El-Khalick, F., Bell, R.L. and Schwartz, R. S. Views of Nature of Science Questionnaire: Toward Valid and Meaningful Assessment of Learners' Conceptions of Nature of Science. Journal of Research in Science Teaching, 39 (6), 497-521.2002.

[10] Khishfe, R and Lederman, N. Teaching Nature of Science within a Controversial Topic: Integrated versus Nonintegrated. Journal of Research in Science Teaching, 43, 4, 395-418. 2006.

[11] Khishfe, R., and Abd-El-Khalick, F. Influence of explicit and eeflective views versus implicit inquiry orientated instruction on sixth graders views of the 
nature of science. Journal of Research in Science Teaching, 39(7), 551-578.2002.

[12] Ryan, A. G. and Aikenhead, G.S. Students' Preconceptions about the Epistemology of Science. Science Education, 76 (6), 559-580.1992.

[13] Palmquist, B. and Finley, F. Preservice Teachers' Views of the Nature of Science During A Postbaccalaureate Science Teaching Program. Journal of Research in Science Teaching, 34, 595615.1997.

[14] Irez, S. Are we prepared?: An Assessment of Preservice Science Teacher Educators' Beliefs About Nature of Science. Science Teacher Education, 90, (6), 1113-1143.2006.

[15] Chang, T. An investigation of Taiwanese graduate students' beliefs about scientific knowledge. Bulletin of National Taiwan Normal University. 40, 583-618, 1995.

[16] Jehng,J.J. Johnson, S.D. and Anderson, R.C. Schooling and students' epistemological beliefs about learning, Contemporary Educational Psychology, 18, 23-35. 1993.

[17] Paulsen, M. B. and Wells, C. T. Domain differences in the epistemological beliefs of college students. Research in Higher Education, 39,(4), 365384.1998.

[18] Marzooghi, R., Fouladchang, M. and Shemshiri, B. Gender and Graduate level differences in epistemological beliefs of Iranian undergraduate students. Journal of Applied Scences. 8, (24), 46984701. 2008.

[19] Samarapungavan, A., Westby, E. L. and Bodner, G. M. Contextual Epistemic Development in Science: A Comparison of Chemistry Students and Research Chemists. Science Education, 90 (3), 468-495.2006.

[20] Khishfe, R and Lederman, N.G. Relationship between instructional context and views of nature of science. International Journal of Science Education, 29 (8), 939-962.2007.

[21] Schwartz, R. S. and Lederman, N.G. What scientists say: Scientists' views of nature of science and relation to science context. International Journal of Science Education, 30(6), 721-771.2008.

[22] Koksal, M.S. Discipline dependent understandings of graduate students in biology education department about the aspects of nature of science, Education and Science, 35, 157, 68-83. 2010.

[23] Irez, S. Nature of science as depicted in Turkish biology textbooks. Science Education, 93(3), 422447.2008.

[24] Taskın, O. Çobanoğlu, E. O. Apaydın, Z. Çobanoğlu, İ.H.Yılmaz, B. and Şahin, B. Undergraduate Students' Perception of Theory Concept. Boğaziçi University Journal of Education, 25 (2), 35-51.2010.

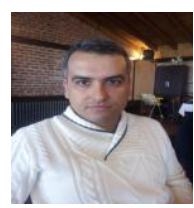

Dr. Mustafa Serdar Koksal is an assistant professor at the Department of Science Education, Inonu University. In teaching, he has been focusing on using explicitreflective approach for teaching NOS. In research, his current interests include epistemological beliefs, risk taking and argumentation. Dr. Kong received his $\mathrm{PhD}$ degree from Faculty of Education in Middle East Technical University. He is a member of ESERA and IRATDE.

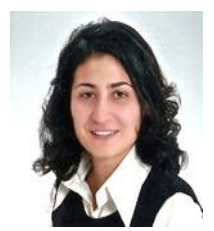

Canan Tunc Sahin has degrees of BE and MS from Bulent Ecevit University Turkey. She has been working for faculty of education over 5 years as a research assistant. She is currently a $\mathrm{PhD}$ student in Marmara University, Istanbul, Turkey. 